\title{
Secretion of anti-Müllerian hormone in the Florida manatee Trichechus manatus latirostris, with implications for assessing conservation status
}

\author{
Rhian C. Wilson ${ }^{1}$, John E. Reynolds III ${ }^{2, *}$, Dana L. Wetzel ${ }^{2}$, Leslie Schwierzke-Wade ${ }^{2}$, \\ Robert K. Bonde ${ }^{3}$, Kevin F. Breuel ${ }^{4}$, William E. Roudebush ${ }^{5}$ \\ ${ }^{1}$ Imperial College London, Silwood Park Campus, Buckhurst Rd., Ascot SL5 7PY, UK \\ ${ }^{2}$ Mote Marine Laboratory, 1600 Ken Thompson Parkway, Sarasota, Florida 34236, USA \\ ${ }^{3}$ US Geological Survey, 2201 NW 40th Terrace, Gainesville, Florida 32605, USA \\ ${ }^{4}$ East Tennessee State University, PO Box 70575, Johnson City, Tennessee 37614, USA \\ ${ }^{5}$ Charleston Southern University, 9200 University Boulevard, Charleston, South Carolina 29423, USA
}

\begin{abstract}
Environmental and anthropogenic stressors can affect wildlife populations in a number of ways. For marine mammals (e.g. the Florida manatee Trichechus manatus latirostris), certain stressors or conservation risk factors have been identified, but sublethal effects have been very difficult to assess using traditional methods. The development of 'biomarkers' allows us to correlate effects, such as impaired reproduction, with possible causes. A recently developed biomarker (anti-Müllerian hormone, AMH) provides an enzyme-linked immunosorbent assay of gonadal function. The study objective was to determine AMH levels in wild manatees. In total, 28 male and 17 female manatee serum samples were assayed. Animal demographics included collection date, body weight $(\mathrm{kg})$ and total length $(\mathrm{cm})$. In certain cases, age of individuals was also known. AMH levels ranged from 160 to $2451.85 \mathrm{ng} \mathrm{ml}^{-1}$ (mean $=844.65 \mathrm{ng} \mathrm{ml}^{-1}$ ) in males and 0.00 to $0.38 \mathrm{ng} \mathrm{ml}^{-1}$ (mean $=0.10 \mathrm{ng} \mathrm{ml}^{-1}$ ) in females. Linear regression analyses revealed a significant relationship between male AMH levels and body weight $\left(\mathrm{R}^{2}=0.452 ; \mathrm{p}<0.001\right)$ and length $\left(\mathrm{R}^{2}=0.338 ; \mathrm{p}<0.001\right)$. Due to the small sample size, regression analyses for female AMH and body weight and length were not significant. This represents the first report of AMH detection in a marine mammal. AMH levels in male manatees are the highest of any species observed to date, whereas levels in females are within reported ranges. Further studies will promote improved conservation decision by assessing AMH levels in the manatee as a function of various stressors including, but not limited to, nutritional status, serious injuries (e.g. watercraft collisions), exposure to biotoxins or contaminants, or disease.
\end{abstract}

KEY WORDS: Manatee $\cdot$ Gonad $\cdot$ Anti-Müllerian hormone $\cdot$ AMH $\cdot$ Conservation

\section{INTRODUCTION}

Environmental and anthropogenic stressors can affect wildlife populations in many ways, some more critical than others. One of the more serious effects can involve fertility and reproductive success. Especially for endangered taxa, it is important to understand whether reproduction is being impaired and, if possible, to mitigate the stressors that may be the cause of impairment. For marine mammals such as the Florida manatee Trichechus manatus latirostris, certain stressors or conservation risk factors have been identified (US Fish and Wildlife Service 2001, Marsh et al. in press), but their sublethal effects have been very difficult to assess using traditional methods. The inability to clearly demonstrate the magnitude and extent of effects of environmental or anthropogenic stressors such as climate change, red tides, underwater noise 
levels, disease and contaminants on manatees and other marine mammals represents a significant impediment to their conservation. Without concrete information to inform decision makers, the motivation to make changes has been lacking. The development and carefully validated use of biomarkers allows scientists to correlate effects, such as impaired reproduction, with possible causes (e.g. chemical contaminants and biotoxins). A recently developed biomarker (anti-Müllerian hormone, AMH) provides an enzyme-linked immunosorbent assay (ELISA) of gonadal function plus fertility potential (Kumar et al. 2010).

During embryonic development in male mammals, secretion of AMH from Sertoli cells is responsible for the regression of the Müllerian duct, and thus the normal development of the male reproductive tract (Picon 1969). Secretion of AMH commences during embryogenesis and continues throughout life. In human males, AMH continues to be produced by the testes until puberty, and then decreases slowly to residual post-pubertal values (Teixeira et al. 2001).

In female mammals, AMH is produced in small amounts by ovarian granulosa cells after birth until menopause, and then becomes undetectable. Since its secretion is not dependent on gonadotropins or other hormones, and is expressed at a constant level independent of the cycle, AMH is attractive as a direct measurement of gonadal function or fertility potential (Roudebush et al. 2008).

$\mathrm{AMH}$ has also been studied in humans to diagnose intersex disorders in children (Lee et al. 2003), precocious puberty and the delayed onset of puberty, cryptorchidism, anorchidism, male gonadal function (Teixeira et al. 2001) and monitoring of granulosa cell cancer patients (Long et al. 2000).

$\mathrm{AMH}$ is present in manatees, and circulating levels differ between sexes and individuals of different maturity status; moreover, it is dependent upon seasonality. Therefore, the objective of this study was to determine $\mathrm{AMH}$ levels in manatees as influenced by sex, presumed sexual maturity and seasonality.

\section{MATERIALS AND METHODS}

Animals sampled. In total, 28 male and 17 female Florida manatee serum samples were obtained. The blood samples were collected from mature and juvenile animals (based on body length) during routine health surveys conducted by the United States Geological Survey (USGS) Sirenia Project on a bi-annual basis. The blood was taken from the brachial vascular bundle of the medial pectoral flipper (Walsh \& Bossart 1999). The whole blood was permitted to clot (15 to $20 \mathrm{~min}$ ) following collection and then centrifuged; samples of sera were subsequently stored at $-80^{\circ} \mathrm{C}$. Frozen samples were not thawed and refrozen prior to analysis.

Animal demographics available for analysis included sex, collection date, body weight (kg) and total length $(\mathrm{cm})$. To determine the reference interval of AMH levels for healthy Florida manatees, the health status of each animal was evaluated prior to inclusion in the study. This is useful, as the effects of inflammation associated with severe injury or disease on circulating AMH levels are unknown. General health status was proxied by standard clinical analysis of serum amyloid A (SAA), carried out as part of the routine USGS animal health assessment. Normal SAA levels are considered to be $\geq 50 \mu \mathrm{g} \mathrm{ml}^{-1}$, with an equivocal range between 50 and $70 \mu \mathrm{g} \mathrm{ml}^{-1}$. Any individuals with SAA levels $\leq 70 \mu \mathrm{g} \mathrm{ml}^{-1}$ are considered to be suffering from an inflammatory disorder (Harr et al. 2006), and thus were excluded from this study.

Serum hormone analysis. Levels of $\mathrm{AMH}$ in the manatee samples were determined by an enzymatically amplified 2-site immunoassay (AMH Gen II; Beckman Coulter). The dual monoclonal antibodies are specific to, and bind only to, the mature conserved region of the $\mathrm{AMH}$, which does not crossreact with other members of the transforming growth factor beta (TGF- $\beta$ ) family, including TGF- $\beta$, activin or inhibin A and B (Kevenaar et al. 2006). Samples were processed in duplicate on a Dynex DS2 automated instrument (Dynex Technologies) following the manufacturer's instructions. Due to the high $\mathrm{AMH}$ concentration observed in male manatees, samples were diluted 1:80 or 1:100 prior to processing. In the first step, $20 \mu \mathrm{l}$ of calibrator standards $(7$ vials, containing concentrations of approximately $0,0.16,0.4,1.2,4.0,10$ and $22.5 \mathrm{ng}$ $\mathrm{ml}^{-1}$, respectively, of AMH in bovine calf serum), low and high controls and unknown samples, and $100 \mu \mathrm{l}$ of assay buffer (protein-based trizma-maleate buffer) were added to microtitration wells coated with antiAMH IgG antibody. The wells were incubated with shaking for $1 \mathrm{~h}$ at room temperature $\left(\sim 25^{\circ} \mathrm{C}\right)$, then washed with phosphate buffer saline containing a nonionic detergent (wash solution). In the second step, $100 \mu \mathrm{l}$ of the AMH antibody-biotin conjugate (biotinylated anti-AMH antibody in protein-based trizmamaleate buffer) was added to each well and shakerincubated for $1 \mathrm{~h}$ at room temperature, and then washed 5 times. In the third step, $100 \mu$ l of streptavidin-labelled, horseradish peroxidase enzyme conjugates in protein-based 2-(N-morpholino)ethanesulfonic acid, MES-TRIS buffer was added to each well. The wells were shaker-incubated for an additional $30 \mathrm{~min}$ at room temperature and washed 5 times as described above. After the final wash step, $100 \mu \mathrm{l}$ of tetramethylbenzidine (TMB) substrate solution was 
added to each well and then shaker-incubated for 10 to $12 \mathrm{~min}$. The colour formation was stopped by addition of $100 \mu \mathrm{l}$ stopping solution $\left(0.2 \mathrm{M} \mathrm{H}_{2} \mathrm{SO}_{4}\right)$ to each well. The degree of enzymatic turnover of the TMB was determined by dual wavelength absorbance measurement at $450 \mathrm{~nm}$ as the primary test filter and $620 \mathrm{~nm}$ as the primary reference filter. Measured absorbance was directly proportional to the concentration of $\mathrm{AMH}$ in the samples. Calibrators were used to plot a log-log linear regression calibration curve of absorbance versus AMH concentration. The AMH concentrations in the samples were then interpolated from the calibration curve. The AMH assay sensitivity was $0.08 \mathrm{ng} \mathrm{ml}^{-1}$, and the intra- and inter-assay coefficients of variation (CVs) were 2.6 and 7.6\%, respectively. The AMH assay was validated for manatees by demonstrating parallelism between serial dilutions of manatee serum (neat, 1:2 to 1:64) and the AMH calibrator-standard curve (Roudebush et al. 2009).

Statistical analysis. Statistical analyses were performed using R 2.10.1 (R.app GUI 1.31 [5537 Leopard build 32-bit], R Foundation for Statistical Computing) statistics software. Serum AMH levels from male and female manatees were analysed based on 2 different factors: (1) presumed maturity status (i.e. juvenile $\leq 269 \mathrm{~cm}$ or adult $\geq 270 \mathrm{~cm}$ ); and (2) season of sample collection (i.e. winter: November to mid-March, and non-winter: late March to October). The division of adult and juvenile Florida manatees based on body length is conventional practice (e.g. Reynolds \& Odell 1991), but there are certainly outliers; for example, Hernandez et al. (1995) found a $2.37 \mathrm{~m}$ long $2 \mathrm{yr}$ old male with some sperm in his testes, and a $2.52 \mathrm{~m}$ long individual with fully spermatogenic testes.

The effect of seasonality on reproductive activity or capacity of male manatees was explored based upon observations of reduced mating behaviour (O'Shea \& Hartley 1995, Rathbun et al. 1995, Reid et al. 1995), reduced spermatogenesis (Hernandez et al. 1995), smaller testicular mass (Reynolds et al. 2004) and lower faecal testosterone concentrations (Larkin et al. 2005) in adult males during winter months.

Linear regression analyses assessed relationships between $\mathrm{AMH}$ and certain demographic parameters for both sexes. Prior to regression analysis, the data were normalised using a log transformation. Student's $t$-tests were used to determine the statistical significance of differences between category means. Data are presented as mean AMH concentrations \pm SEM. Differences were considered significant if $p<0.05$.

\section{RESULTS}

AMH levels ranged from 160 to $2451.85 \mathrm{ng} \mathrm{ml}^{-1}$ (mean $844.65 \mathrm{ng} \mathrm{ml}^{-1}$ ) in males and 0.0 to $0.38 \mathrm{ng} \mathrm{ml}^{-1}$ (mean $0.10 \mathrm{ng} \mathrm{ml}^{-1}$ ) in females (Table 1). Linear regression analyses showed a significant relationship between male $\mathrm{AMH}$ levels and body weight $(\mathrm{AMH}=$ $-2.65+[1.893 \times \log$ weight $] ; \mathrm{R}^{2}=0.43 ; \mathrm{p}<0.01 ;$ Fig. 1$) ;$ a significant relationship between $\mathrm{AMH}$ levels and total length in males $(\mathrm{AMH}=-8.771+[4.738 \times \log$ length]); $\mathrm{R}^{2}=0.33$; $<<0.001$; Fig. 2); and no significant relationship between $\mathrm{AMH}$ levels and either body weight or length in females.

The potential effect of both seasonality and maturity status on AMH levels was examined (Table 2). In males, levels of AMH were highest in adults during the non-winter season. Student's $t$-tests found a significant difference $(\mathrm{p}<0.01)$ between AMH levels in adult males in winter (mean $=487.57 \mathrm{ng} \mathrm{ml}^{-1}$ ) and adult males in non-winter $\left(\right.$ mean $\left.=1269.5 \mathrm{ng} \mathrm{ml}^{-1}\right)$. Due to

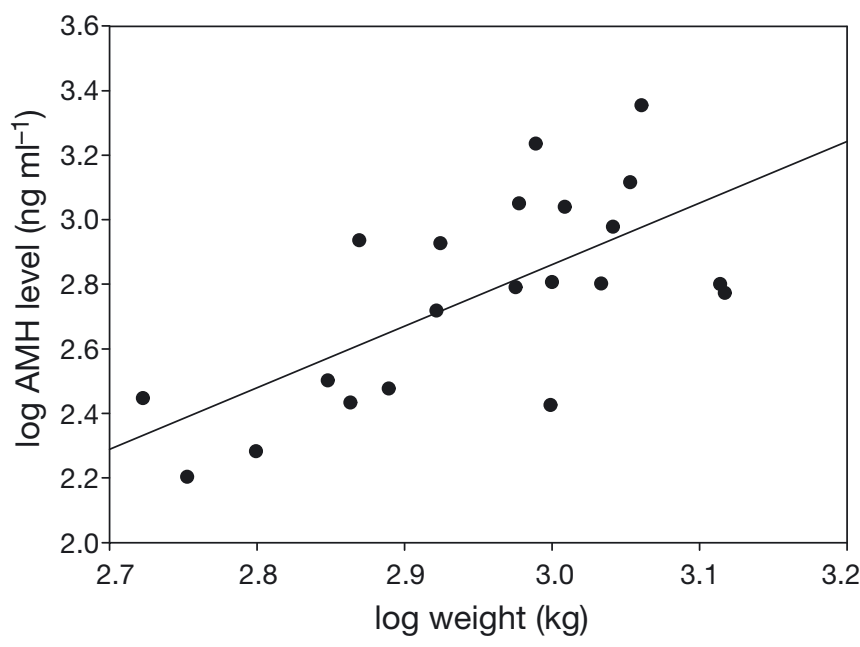

Fig. 1. Trichechus manatus latirostris. Linear regression of weight $(\mathrm{kg})$ against anti-Müllerian hormone (AMH) levels $\left(\mathrm{ng} \mathrm{ml}^{-1}\right.$ ) for male manatees following log transformation

Table 1. Trichechus manatus latirostris. Population demographics and serum anti-Müllerian hormone (AMH) concentrations in male and female Florida manatees (means \pm SEM). SAA: serum amyloid A

\begin{tabular}{|lcccccc|}
\hline Gender & $\begin{array}{c}\text { Samples } \\
(\mathrm{n})\end{array}$ & $\begin{array}{c}\text { Weight } \\
(\mathrm{kg})\end{array}$ & $\begin{array}{c}\text { Length } \\
(\mathrm{cm})\end{array}$ & $\begin{array}{c}\text { SAA } \\
\left(\mu \mathrm{m} \mathrm{ml}^{-1}\right)\end{array}$ & $\begin{array}{c}\text { Mean AMH } \\
\left(\mathrm{ng} \mathrm{ml}^{-1}\right)\end{array}$ & $\begin{array}{c}\text { AMH range } \\
\left(\mathrm{ng} \mathrm{ml}^{-1}\right)\end{array}$ \\
\hline Male & 28 & $928.85 \pm 50.10$ & $279.57 \pm 4.75$ & $15.54 \pm 2.26$ & $844.65 \pm 124.70$ & $160-2451.85$ \\
Female & 17 & $882.50 \pm 18.05$ & $274.53 \pm 5.47$ & $19.07 \pm 4.07$ & $0.10 \pm 0.0228$ & $0.00-0.38$ \\
\hline
\end{tabular}




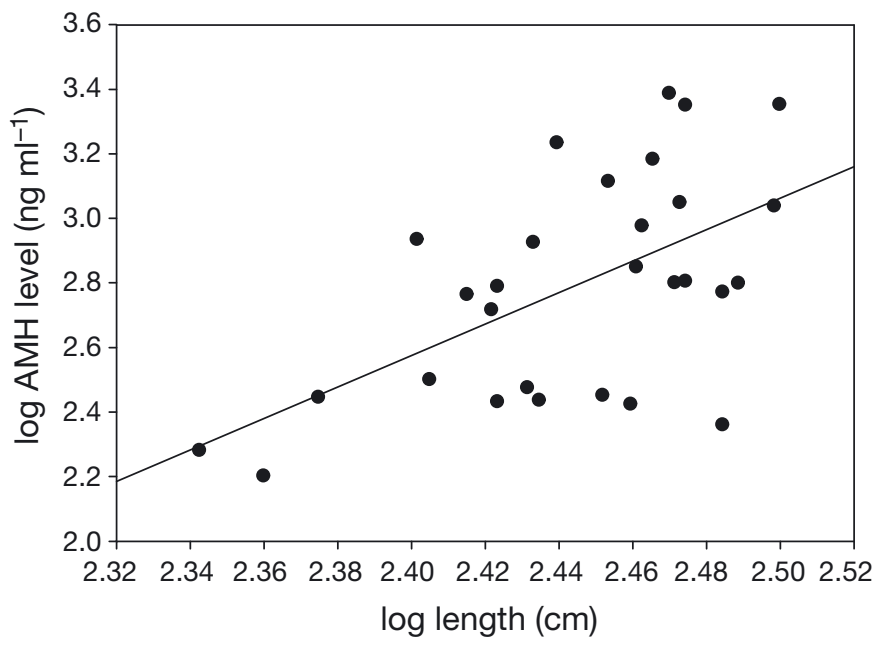

Fig. 2. Trichechus manatus latirostris. Linear regression of length $(\mathrm{cm})$ against anti-Müllerian hormone (AMH) levels (ng $\mathrm{ml}^{-1}$ ) for male manatees following log transformation

the small sample size of juvenile male non-winter animals, comparisons could not be made between the juvenile seasonality classes and between the adult and juvenile non-winter samples. In females, no statistical difference was found for AMH levels between or among any of the assigned categories; however, this may have been a result of smaller sample sizes, particularly for the winter female samples, and thus lower statistical power.

\section{DISCUSSION}

In male mammals such as humans, secretion of $\mathrm{AMH}$ by Sertoli cells commences during embryogenesis and continues throughout life. AMH continues to be produced by the testes until puberty and then decreases slowly to residual post-puberty values (Teixeira et al. 2001). Serum AMH levels may be an appropriate

Table 2. Trichechus manatus latirostris. Serum anti-Müllerian hormone (AMH) concentrations in male and female manatees in season and maturity status categories, given as means \pm SEM. Values in bold are significantly different from each other $(p<0.05)$

\begin{tabular}{|llccc|}
\hline Gender & Category & $\begin{array}{c}\text { Serum } \\
\text { samples }(\mathrm{n})\end{array}$ & $\begin{array}{c}\text { Mean AMH } \\
\left(\mathrm{ng} \mathrm{ml}^{-1}\right)\end{array}$ & $\begin{array}{c}\text { AMH range } \\
\left(\mathrm{ng} \mathrm{ml}^{-1}\right)\end{array}$ \\
\hline Male & Adult winter & 7 & $\mathbf{4 8 7 . 5 7} \pm \mathbf{9 7 . 6 5}$ & $230-952$ \\
& Adult non-winter & 13 & $\mathbf{1 2 6 9 . 5} \pm \mathbf{2 0 4 . 4 7}$ & $274-2451.85$ \\
& Juvenile winter & 7 & $422.14 \pm 97.16$ & $160-864$ \\
& Juvenile non-winter & 1 & $582.72 \pm 0.00$ & 582.72 \\
Female & Adult winter & 4 & $0.009 \pm 0.006$ & $0.0-0.024$ \\
& Adult non-winter & 6 & $0.032 \pm 0.007$ & $0.0-0.38$ \\
& Juvenile winter & 2 & $0.1 \pm 0.0$ & $0.1-0.1$ \\
& Juvenile non-winter & 5 & $0.125 \pm 0.0146$ & $0.096-0.162$ \\
\hline
\end{tabular}

marker of the function and maturation of Sertoli cells in the males and, as such, an indicator of spermatogenesis (Sinisi et al. 2008, Tüttelmann et al. 2009).

This study represents the first report of AMH detection in a marine mammal. Given the utility of enhanced knowledge of reproductive state and capacity for assessing conservation status, as well as the concerns that exist with regard to conservation status of marine mammals as a group (e.g. Reynolds et al. 2005, Marine Mammal Commission 2008), this first step may lead to significant applications.

$\mathrm{AMH}$ levels in male manatees are the highest observed in any mammalian species reported to date. Elephants (Order: Probiscidea) have a close phylogenetic relationship with manatees and their relatives (Order: Sirenia; e.g. see Reynolds \& Odell 1991). Perhaps not surprisingly, levels of AMH reported for both African Loxodonta africana and Asian Elephas maximus elephants are elevated in comparison with most other mammalian species (Dow et al. 2011). As with manatees, the levels of AMH in male elephants are also significantly higher than in females (Dow et al. 2011). However, the levels observed in male Florida manatees greatly exceed levels seen in either species of elephant.

By comparison, AMH levels in female manatees are within reported ranges for other mammalian species. The magnitude of the difference in $\mathrm{AMH}$ levels found between the manatee sexes is also seen in elephants, where the levels found in males are more than 100 times greater than those in females (Dow et al. 2011).

In male manatees, levels of circulating $\mathrm{AMH}$ were correlated with both body length $(\mathrm{cm})$ and body weight $(\mathrm{kg})$. Testicular weight increases exponentially with body length (Reynolds et al. 2004), supporting the relationship found between AMH levels and body length in this study. This is likely due to the greater number of Sertoli cells, and therefore higher levels of hormone, that would be present in a larger testicular tissue mass. Body length is the standard metric used for estimating or inferring relative maturity in manatees. For consistency with other studies, therefore, body length was also used in this study as a means of separating the individuals sampled into adults and juveniles.

The levels of $\mathrm{AMH}$ were highest in adult males sampled outside the winter season. Since maturity status affects the levels of AMH in other mammalian species, these results are consistent with the observation that AMH levels act as a marker for gonadal function in male manatees.

The results are also consistent with those of Hernandez et al. (1995), who 
found that not all large male Florida manatees were spermatogenic, even outside the winter season. Since Hernandez et al. (1995) conducted their assessments using carcasses (for which biases may exist), rather than presumed-healthy, living animals (as we did), it is interesting that we also found some very large manatees with low fertility (see Figs. $1 \& 2$ ). It is possible that such individuals are in a state of long-term or even permanent cessation of reproductive activity; it is also possible, even likely, that adult manatees enter periods of greater or lesser spermatogenic activity and fertility associated with intensive bouts of promiscuous breeding behaviour and sperm competition.

Similarly, Larkin et al. (2005) used a radioimmunoassay kit to assess testosterone levels in captive and some free-ranging manatees; these authors independently confirmed the relationship of hormone levels and season. Interestingly, there was some overlap in testosterone levels of adult male and female manatees sampled. Whereas testosterone is primarily secreted in the testes of males and the ovaries of females, small amounts are also secreted by the adrenal glands. By contrast, AMH is only produced by gonadal tissue, and serum levels directly reflect folliculogenesis/spermatogenesis activity; therefore, it is a more sensitive marker of reproductive potential than any other molecule, e.g. estradiol or testosterone (Roudebush et al. 2008).

In human females, $\mathrm{AMH}$ is produced in small amounts by ovarian granulosa cells after birth until menopause, and then becomes undetectable. AMH regulates folliculogenesis by inhibiting excessive follicular recruitment by follicle stimulating hormone (Roudebush \& Mattke 2009). AMH can also serve as a marker for ovarian reserve and, thus, of reproductive potential in females (Roudebush et al. 2008). In female manatees, no correlation was found between the levels of AMH and morphological parameters such as body length and weight. The low levels in the females may be due in part to a dilution effect of the hormone in the serum. The manatee ovary (Rodrigues et al. 2008) is approximately the same size as a human ovary (Lass et al. 1997), yet the mass of an adult manatee can be an order of magnitude greater than the mass of an adult human. Thus the proportion of AMH found in manatee circulation would be relatively small, and we are therefore unable to confirm whether $\mathrm{AMH}$ levels in the female manatee correspond to maturity status and are also indicative of gonadal function.

As noted, AMH likely functions during spermatogenesis in male mammals and can act as a marker for Sertoli cell function. For this reason, the effects of seasonality were examined in both male and female manatees, as spermatogenesis (Hernandez et al. 1995) and testicular mass (Reynolds et al. 2004) are reduced during the winter months (November to mid-March) rela- tive to the non-winter months (late March to October). In fact, no fully spermatogenic males were found during the winter months. In our study, levels of $\mathrm{AMH}$ were highest in adult males during the non-winter months, suggesting that peak AMH levels correspond to peak spermatogenesis in this species.

In addition, most births in wild manatees occur during the non-winter months (O'Shea \& Hartley 1995, Rathbun et al. 1995, Reid et al. 1995). Since gestation in manatees is known to be 12 to $14 \mathrm{mo}$, females may also undergo a seasonal depression in their reproductive capabilities during winter. In females, neither seasonality nor relative sexual maturity impacted levels of circulating AMH.

Since AMH allows us to assess the fertility potential of male manatees, we will soon be able to relate it to a range of parameters including, but not limited to, geographic location, nutritional status, exposure to biotoxins or contaminants, or disease. Using a different hormone (inhibin B), we expect to show the same correlation with female manatees (D. L. Wetzel, J. E. Reynolds et al. unpubl. data). The capacity to evaluate the 'reproductive quality' of individuals comprising a population and to relate effects of environmental or anthropogenic stressors or conservation risk factors to reproductive potential makes the assessment of $\mathrm{AMH}$ and inhibin $\mathrm{B}$ extremely useful for determining the true conservation of a species or population (e.g. Reynolds et al. 2009). Effective and focused conservation and mitigation can be optimised in light of clear indications of effects of stressors on critical biological functions such as reproduction.

Acknowledgements. We thank all individuals who assisted with wild manatee captures, handling and sample processing. Samples were collected under US Fish and Wildlife Service Wildlife Research Permit Nos. MA773494-8 (FWC-FWRI) and MA791721 (USGS Sirenia Project). Any use of trade, product or firm names is for descriptive purposes only and does not imply endorsement by the US government.

\section{LITERATURE CITED}

Dow T, Roudebush WE, Parker FN, Brown JL (2011) Influence of age and gender on secretion of anti-Müllerian hormone in Asian (Elephas maximus) and African (Loxodonta africana) elephants. Theriogenology 75:620-627

- Harr K, Harvey J, Bonde R, Murphy D and others (2006) Comparison of methods used to diagnose generalized inflammatory disease in manatees (Trichechus manatus latirostris). J Zoo Wildl Med 37:151-159

Hernandez P, Reynolds JE III, Marsh H, Marmontel M (1995) Age and seasonality in spermatogenesis of Florida manatees. In: O'Shea TJ, Ackerman BB, Percival HF (eds) Population biology of the Florida manatee. Information and Technology Rep 1. US Department of the Interior, National Biological Service, Washington, DC, p 84-97 
Kevenaar ME, Meerasahib MF, Kramer P, van de Lang-Born BM and others (2006) Serum anti-mullerian hormone levels reflect the size of the primordial follicle pool in mice. Endocrinology 147:3228-3234

Kumar A, Kalra B, Patel A, McDavid L, Roudebush WE (2010) Development of a second generation anti-Müllerian hormone (AMH) ELISA. J Immunol Methods 362:51-59

Larkin ISV, Gross TS, Reep RL (2005) Use of faecal testosterone concentrations to monitor male manatee (Trichechus manatus latirostris) reproductive status. Aquat Mamm 31:52-61

Lass A, Skull J, McVeigh E, Margara R, Winston RML (1997) Measurement of ovarian volume by transvaginal sonography before ovulation induction with human menopausal gonadotrophin for in vitro fertilization can predict poor response. Hum Reprod 12:294-297

Lee M, Misra M, Donahoe P, MacLaughlin D (2003) MIS/AMH in the assessment of cryptorchidism and intersex conditions. Mol Cell Endocrinol 211:91-98

Long WQ, Ranchin V, Pautier P, Belville C and others (2000) Detection of minimal levels of serum anti-Müllerian hormone during follow-up of patients with ovarian granulose cell tumor by means of a highly sensitive enzyme-linked immunosorbent assay. J Clin Endocrinol Metab 85:540-544

Marine Mammal Commission (2008) The biological viability of the most endangered marine mammals and the costeffectiveness of protection programs. A report to Congress from the Marine Mammal Commission, Bethesda, MD

Marsh H, O'Shea TJ, Reynolds JE III (in press) Ecology and conservation of Sirenia: dugongs and manatees. Cambridge University Press, Cambridge

O'Shea TJ, Hartley WC (1995) Reproduction and early-age survival of manatees at Blue Spring, Upper St. Johns River, Florida. In: O'Shea TJ, Ackerman BB, Percival HF (eds) Population biology of the Florida manatee. Information and Technology Rep 1. US Department of the Interior, National Biological Service, Washington, DC, p 157-170

Picon R (1969) Action of the fetal testis on the development in vitro of the Müllerian ducts in the rat. Arch Anat Microsc Morphol Exp 58:1-19

Rathbun GB, Reid JP, Bonde RK, Powell JA (1995) Reproduction in free-ranging female manatees. In: O'Shea TJ, Ackerman BB, Percival HF (eds) Population biology of the Florida manatee. Information and Technology Rep 1. US Department of the Interior, National Biological Service, Washington, DC, p 135-156

Reid JP, Bonde RK, O'Shea TJ (1995) Reproduction and mortality of radio-tagged and recognizable manatees on the Atlantic coast of Florida. In: O'Shea TJ, Ackerman BB,

Editorial responsibility: Brendan Godley, University of Exeter, Cornwall Campus, UK
Percival HF (eds) Population biology of the Florida manatee. Information and Technology Rep 1. US Department of the Interior, National Biological Service, Washington, DC, p 171-191

Reynolds JE III, Odell DK (1991) Manatees and dugongs. Facts on File, New York, NY

> Reynolds JE III, Rommel SA, Pitchford ME (2004) The likelihood of sperm competition in manatees - explaining an apparent paradox. Mar Mamm Sci 20:464-476

Reynolds JE III, Perrin WF, Reeves RR, Ragen TJ, Montgomery S (eds) (2005) Marine mammal research: beyond crisis management. Johns Hopkins University Press, Baltimore, MD

Reynolds JE III, Wetzel DL, Breuel KF, Roudebush WE (2009) Assessment of mammalian reproductive potential and utility for conservation: a case study for the West Indian manatee, Trichechus manatus. Proc 18th Biennial Conf Biol Mar Mamm, 12-16 October, 2009, Quebec

Rodrigues FR, Da Silva VM, Barcellos JF, Lazzarini SM (2008) Reproductive anatomy of the female Amazonian manatee Trichechus inunguis Natterer, 1883 (Mammalia: Sirenia). Anat Rec 291:557-564

Roudebush WE, Mattke JM (2009) Anti-Müllerian hormone and the embryologist. J Clin Embryol 12:15-20

Roudebush WE, Kivens WJ, Mattke JM (2008) Biomarkers of ovarian reserve. Biomark Insights 3:259-268

Roudebush WE, Wetzel DL, Breuel KF, Reynolds JE III (2009) Validation of an anti-Mullerian hormone (AMH) ELISA for use in an endangered marine mammal, the West Indian manatee (Trichechus manatus). Biol Reprod 81:214

Sinisi AA, Esposito D, Maione L, Quinto MC and others (2008) Seminal anti-Müllerian hormone level is a marker of spermatogenic response during long-term gonadotropin therapy in male hypogonadotropic hypogonadism. Hum Reprod 23:1029-1034

Teixeira J, Maheswaran S, Donahoe PK (2001) Müllerian inhibiting substance: an instructive developmental hormone with diagnostic and possible therapeutic applications. Endocr Rev 22:657-674

Tüttelmann F, Dykstra N, Themmen AP, Visser JA, Nieschlag E, Simoni M (2009) Anti-Müllerian hormone in men with normal and reduced sperm concentration and men with maldescended testes. Fertil Steril 91:1812-1819

US Fish and Wildlife Service (2001) Florida Manatee recovery plan (Trichechus manatus latirostris), 3rd revision. US Fish and Wildlife Service, Atlanta, GA

Walsh MT, Bossart GD (1999) Manatee medicine. In: Fowler M, Miller E (eds) Zoo and wild animal medicine, 4th edn. W.B. Saunders Company, Philadelphia, PA, p 507-516

Submitted: September 7, 2010; Accepted: March 23, 2011 Proofs received from author(s): May 16, 2011 